\title{
Contribution to knowledge on ontogenetic developmental stages of Lepidodendron mannebachense Presl, 1838
}

\author{
STANISLAV OPLUŠTIL
}

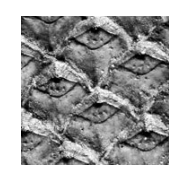

\begin{abstract}
A new reconstruction of Lepidodendron mannebachense is proposed here based on collection of well-preserved compressions from middle Moscovian volcanoclastics of the Radnice Basin, Czech Republic. These specimens that represent remains of juvenile and matured individuals make progress in our current knowledge on ontogeny of this species and help us to improve its whole plant reconstruction. The juvenile stage was characterised by an unbranched columnar stem. The mature stage of L. mannebachense had an umbrella-like canopy produced by combination of more or less isotomous apical dichotomies of the stem and main branches with anisotomous pseudomonopodial branching. Dichotomous branching built the frame of the crown and continued until the limit for meristem division was reached. However, most of thin terminal shoots were anisotomous lateral branches growing from the main dichotomies. Some of them as well as terminal branches bore cones on their tips. Only a narrow zone of leaves was maintained at any stage of tree development. In the mature stage, leaves were retained only at apical parts of terminal shoots. L. mannebachense was a monocarpic type of plant with a determinate growth. $•$ Key words: Lepidodendron mannebachense, ontogeny, Pennsylvanian.
\end{abstract}

OPLUŠTIL, S. 2010. Contribution to knowledge on ontogenetic developmental stages of Lepidodendron mannebachense Presl, 1838. Bulletin of Geosciences 85(2), 303-316 (7 figures). Czech Geological Survey, Prague. ISSN 1214-1119. Manuscript received January 16, 2010; accepted in revised form April 26, 2010; published online June 3, 2010; issued June 30, 2010.

Stanislav Opluštil, Faculty of Sciences, Charles University, Albertov 6, 12843 Prague 1, Czech Republic; oplustil@natur.cuni.cz.

Lepidodendrid lycopsids dominated many early to middle Pennsylvanian tropical wetlands. During this period these spectacular plants contributed up to 60 to $80 \%$ to the biomass production in peat-forming habitats (Phillips et al. 1985). Therefore it is not surprising that most of the reconstructions depict the Pennsylvanian coal measure forests as dominated by the arborescent lycopsids (e.g. Walton in MacGregor \& Walton 1948). However, most reconstructions, especially the earlier ones, show lepidodendrids only as mature trees with an umbrella-like canopy produced by dichotomous branching (e.g. Hirmer 1927). This interpretation was based on scarce findings of some large specimens (e.g. Lindley \& Hutton 1835/37, Scott 1920) and on commonly found fragments of branch compressions showing more or less isotomous dichotomous patterns. This traditional and simplified view of these bizarre trees started to change with an onset of systematic study of anatomically preserved specimens and compressions of exceptionally complete lepidodendrid tree remains (e.g. Walton 1935, Andrews \& Murdy 1958, Eggert 1961, Delevoryas 1964 and especially DiMichele 1979a, b, 1980; Wnuk 1985, 1989). These studies proved that whole plant morphology of these plants is much more complex and that various growth strategies exist (for an overview see Phillips \& DiMichele 1992 and DiMichele \& Phillips 1994). Therefore it is not surprising that new findings that contribute to understanding of whole-plant reconstruction of particular species are of interest to paleobotanists. Recently, several specimens of L. mannebachense that can contribute to our knowledge on ontogenetic developmental stages of this common arborescent lycopsid have been found when revising fossil plant collections in the Museum of the Geological Survey of Austria in Vienna, the National Museum in Prague and the West Bohemian Museum in Pilsen. The whole plant reconstruction of juvenile and mature developmental stages of this species is therefore the main target of the paper.

\section{Ontogeny of lepidodendrid lycopsids}

Our present-day knowledge on ontogeny of lepidodendrid lycopsids and their architecture is based on numerous observations of petrified and compression specimens 
(e.g. Andrews \& Murdy 1958; Eggert 1961; DiMichele 1979a, b; 1980, 1981; Wnuk 1985, 1989). Hypothetical reconstructions of very early ontogenetic stages of lepidodendrids depict these plants as leaf-bearing domed to cone-shaped poles stabilized by dichotomously branched anchoring and water absorbing rhizomorphs bearing helically arranged roots (Phillips \& DiMichele 1992). It is supposed that when such a stage was once established it was capable of fast polar growth as well as of secondary thickening (e.g. Andrews \& Murdy 1958, Eggert 1961, Phillips $\&$ DiMichele 1992). This resulted in development of an unbranched stem bearing long grass-like leaves thus resembling Sigillaria more than Lepidodendron. The anatomical studies have shown that the main stem underwent secondary thickening that decreased in extent up the stem as the apical meristem enlarged and produced more primary tissue. Consequently, much more secondary growth occurred in the lower parts of the stem (e.g. Eggert 1961). It is assumed that lepidodendrid leaf cushions once produced, did not change their size during the secondary growth and subsequent thickening of the stem (e.g. Walton 1935, Egger, 1961, Wnuk 1985, Phillips \& DiMichele 1992). As a result, on a mature Lepidodendron stem we find largest leaf cushions on the main axis; they become progressively smaller in distal parts of branches and smallest on the ultimate branches as the meristem reduced in size after each branching. Since the size of leaf cushions (especially the length) remained the same once they appeared on the stem, the secondary growth and stem thickening could be accommodated by expansion of the inter-cushion areas (Thomas 1966, 1970; Thomas \& Watson 1976; Wnuk 1985). However, potential for inter-cushion expansion varied among species. Those with high potential could retained leaf cushions (primary cortical tissues) over a large part of the stem (e.g. Lepidodendron rimosum, L. aculeatum) whereas species with low potential sloughed them off soon (e.g. L. bretonense which is probably Synchysidenron) and only a narrow zone of leaf cushion-bearing cortex remained below the stem apex at any stage of its development (Thomas 1970, Wnuk 1985). DiMichele (1983) mentioned extensive lateral expansion of cells in the base of the leaf cushions and in the outer parts of the periderm of Lepidodendron hickii (corresponds probably to compression species L. aculeatum) that allowed leaf cushions to be retained longer.

Observations of large specimens also revealed that unbranched stems had the longest leaves and that leaf length decreased as branch diameter decreased with each dichot- omy (e.g. Hirmer 1927, Němejc 1947, Eggert 1961, Wnuk 1985). When a certain height and diameter was reached, the stem started branching. Depending whether main branches were produced by dichotomy or pseudomonopodialy, the trees had either an umbrella-like crown or a main stem with lateral branches leaving a large ulodendroid scars on the stem after branch abscission (e.g. DiMichele \& Phillips 1985, 1994). Cones were mostly produced at the tips of the branches.

\section{Material}

Specimens discussed and figured in this paper are stored in the collections of the Geologische Bundesanstalt Museum (Geological Survey Museum) in Vienna, Austria, in the National Museum in Prague, Czech Republic and in the West Bohemian Museum in Pilsen, Czech Republic. Although the total number of specimens in these collections belonging to this species is much higher, only five of them were selected for the purpose of this study. These specimens can significantly improve our understanding of whole plant morphology of this species in various stages of its ontogenic development whereas other specimens do not extend our current concept of the species.

In the Geological Survey Museum in Vienna, two specimens were selected. The larger one is the specimen No. 6857 preserved in about $900 \mathrm{~mm}$ long slab. It is a fragment of an apical part of vegetative stem described by Ettingshausen (1854, plate 27) as Lepidodendron sternbergii Lindley \& Hutton. Re-examination of the specimen by the present author clearly proved that it is Lepidodendron mannebachense. The second one (No. 6886) is also an Ettingshausen (1854, plate 25) specimen of Lepidodendron brevifolium Ettingshausen. It preserves terminal leafy shoots. From the paleontological collection of the West Bohemian Museum in Pilsen, only one specimen (F 233) was selected. It shows terminal leafy shoots one of them with an attached cone. In the National Museum in Prague, among many specimens identified as Lepidodendron mannebachense, only two of them (E 5734, E 4745) have been selected for detailed description. The specimen E 5734 is a large fragment of branch system showing several orders of branching. Although it is identified as L. dichotomum, re-examination of the specimen revealed that it is also L. mannebachense. The second specimen (E 4745) is the Sternberg's syntype of $L$. dichotomum. The specimen preserves terminal and near-terminal leafy shoots and

Figure 1. A - the whole view of the Ettingshausen (1854) specimen No. 6857 representing an apical part of the stem of juvenile Lepidodendron mannebachense. Scale bar $100 \mathrm{~mm}$. $\bullet \mathrm{B}$ - detail of leaf cushions of the same specimen about $150 \mathrm{~mm}$ below the blunt apex. Scale bar $10 \mathrm{~mm}$. $\bullet \mathrm{C}$ - detail of leaf cushions about $400 \mathrm{~mm}$ below the apex. Scale bar $10 \mathrm{~mm}$. $\bullet \mathrm{D}$ - detail of leaf cushions of the isolated stem fragment in the lower part of the specimen. Scale bar $10 \mathrm{~mm}$. E - detail of a single leaf cushion from the Fig. 1D showing leaf scar and infrafoliar parichnos imprints. Scale bar $2.5 \mathrm{~mm}$. 


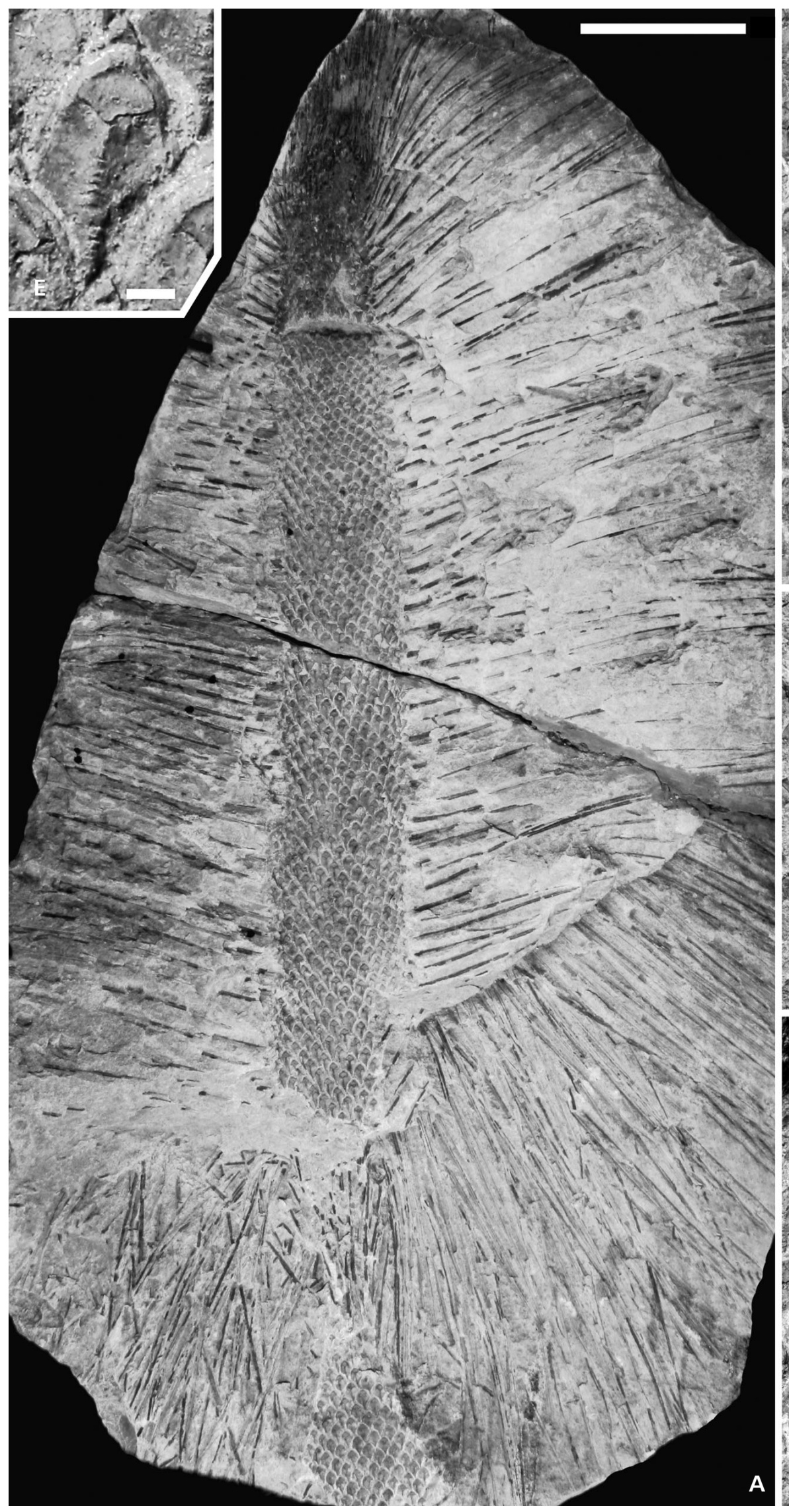

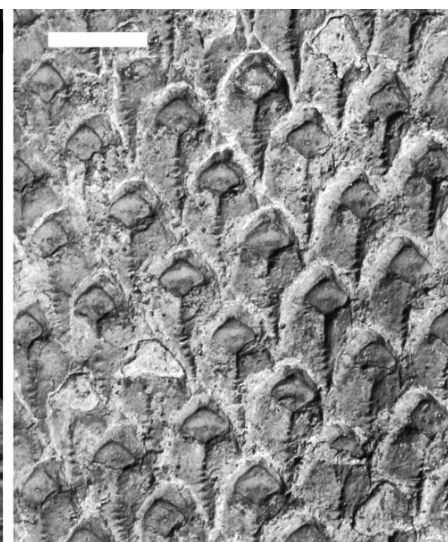

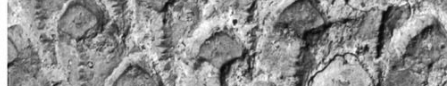
5. If

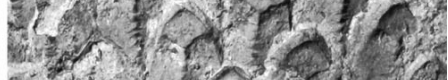

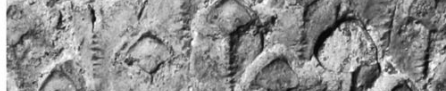

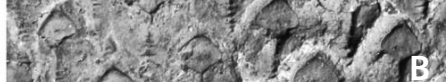

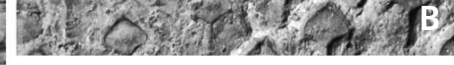

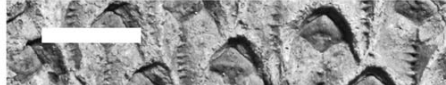
an 1 a 5

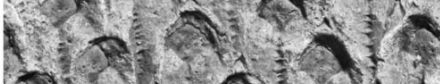

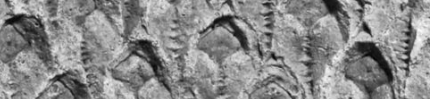
s. $(x-1)+(1.3)$ a. 912 and

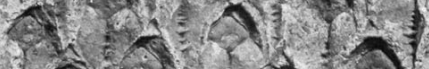

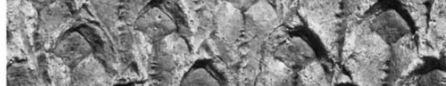

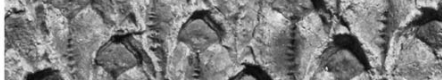

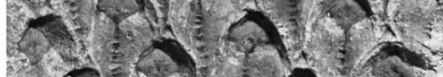

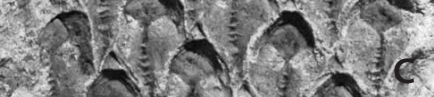

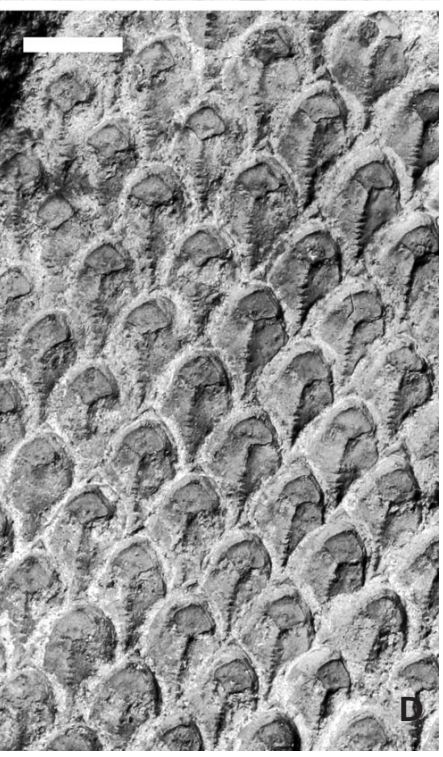


branches that clearly belong to L. mannebachense. This interpretation is fully in agreement with the opinion of Němejc $(1946,1947)$ who recognized that Sternberg mixed under the name of $L$. dichotomum two different species: L. obovatum and L. longifolium, the former having infrafoliar parichnos the latter without it. Both specimens from the National Museum have infrafoliar parichnos and there is no doubt they belong L. obovatum. Unfortunately, Sternberg (1820) involved under his L. obovatum (Sagenaria obovata) two evidently different species; L. aculeatum and Presl's L. mannebachense (1838) which resulted in more than a century-lasting taxonomical and nomenclature confusion in a literature. Němejc (1947) solved up only taxonomical part of the problem when he clearly stated differences between L. aculeatum and L. obovatum and provided their synonymy. Unfortunately he retained a confusing name L. obovatum. This nomenclature problem persisted until Thomas (1970) selected Presl's (1838) L. mannebachense as a suitable name to replace L. obovatum. Presl's species established only on a single specimen (figured on the plate 68, fig. 2) fully corresponds to Němejc's (1947) interpretation of $L$. obovatum, the name which Thomas (1970) placed into the synonymy of L. aculeatum.

All the specimens selected for description were collected in Svinná, in the northern part of the Radnice Basin, Czech Republic and are preserved in a volcanoclastic rock called Bělka. This about $500 \mathrm{~mm}$ thick tuff bed forms the roof of the Lower Radnice Coal of early Bolsovian ( middle Moscovian) age. The Bělka preserves an in situ buried peat-forming flora and has provided many large and complete specimens (Opluštil et al. 2007, 2009a, b; Libertín et al. 2009a).

\section{Description of the specimens of Lepidodendron mannebachense}

The specimen No. 6857 consists of two pieces of vegetative stem both with the same type of leaf cushions (Fig. 1A). The smaller fragment in the lower part of the slab represents an about $130 \mathrm{~mm}$ long and $65 \mathrm{~mm}$ wide impression of the stem with leaf cushions pointing up to the second stem fragment. The original width of the stem had to be larger because no stem margins are preserved. The second fragment is a much larger piece of straight leafy axis terminated by a blunt apex (Figs 1A, 2A), which evidently represents a natural/biological termination of this vegetative axis. This stem fragment is about $570 \mathrm{~mm}$ long but including leaves at the stem apex its length increases to about $680 \mathrm{~mm}$. The width of the stem tapers to the apex very gradually; in the lower part, about $500 \mathrm{~mm}$ below the apex, it is $82 \mathrm{~mm}$ wide, $300 \mathrm{~mm}$ below the apex it is $70 \mathrm{~mm}$ wide but only $62 \mathrm{~mm}$ and $42 \mathrm{~mm}$ wide about $140 \mathrm{~mm}$ and $40 \mathrm{~mm}$ below the apex respectively. The stem is preserved mostly as an impression in the tuff matrix but apical part about $120 \mathrm{~mm}$ long is preserved as a compression, the pith of which is filled by the same volcanoclastic rock embedding the stem. Leaf cushions are preserved along the whole length although at the apex they are partly hidden by long grass-like leaves. Leaves are attached to leaf cushions along both sides of the stem throughout its whole length (Fig. 1A). Both stem fragments posses leaf cushions of the same type pointing in the same direction. No indications of branching or branch scars were observed.

Leaf cushions are raised, rhomboidal, vertically and horizontally asymmetrical, approximately twice as long as wide, and arranged into a helix. One of lateral angles is rounded whereas the opposite one is more angular as a result of asymmetry of leaf cushions (Fig. 1B-E). The lower end is more acute than the upper one. Both ends are very slightly inflected in opposite directions. The cushions have distinct lateral lines extending from the lateral corners of the leaf scar to the outer edge of the cushions. The lateral lines divide the cushion into an upper and lower field. The upper field of the leaf cushion is very small with a short, indistinct keel. Striations typical of the upper field of this species as described by Thomas (1970) were observed only exceptionally probably due to a coarse nature of the tuff matrix. The lower field is large and with a distinct keel that bears several prominent but short transverse folds or notches (Fig. 1B-E). The leaf scar is located in upper half of the leaf cushion. It is rhomboidal with a rounded upper margin. Its lower margin is in a form of wide ' $V$ '. Leaf scars are fairly large compared to the whole leaf cushion. They are between 3.5 and $5.0 \mathrm{~mm}$ wide and 2.6 and $3.5 \mathrm{~mm}$ high depending either on preservation or on the position on the stem. The width of leaf scar reaches about one-third to one-half of the width of leaf cushion. Leaf scars bear two characteristic parichnos scars with one vascular bundle imprint between them. Below the leaf scar there are two distinct infrafoliar parichnos (Figs 1B-D, 2B-D). The size of leaf cushions changes throughout the length of the specimen only slightly. They are largest in the lower part, about $500 \mathrm{~mm}$ below the apex, where they are about $17 \mathrm{~mm}$ long and $7.5 \mathrm{~mm}$ wide on average. Acropetally, about $250 \mathrm{~mm}$ below the apex, they are $14.5 \mathrm{~mm}$ long and $6.5 \mathrm{~mm}$ wide. A few centimetres below the apex they are about $10-11 \mathrm{~mm}$ long and 6-7 mm wide. Leaf cushions are densely spaced without inter-cushion areas between them (Fig. 1). There is only slight distortion of leaf cushion shape or size toward the sides of the stem.

Single-veined, grass-like leaves are incompletely preserved. The longest but still incomplete leaves are about $250 \mathrm{~mm}$ long and about $3.5-4.5 \mathrm{~mm}$ wide at the base where they are connected to the leaf cushion (Fig. 2). However, they decrease rapidly in width to be about $2.8-3.2 \mathrm{~mm}$ wide throughout most of their length. The leaves are mostly straight or only slightly bent downward. Leaves of 

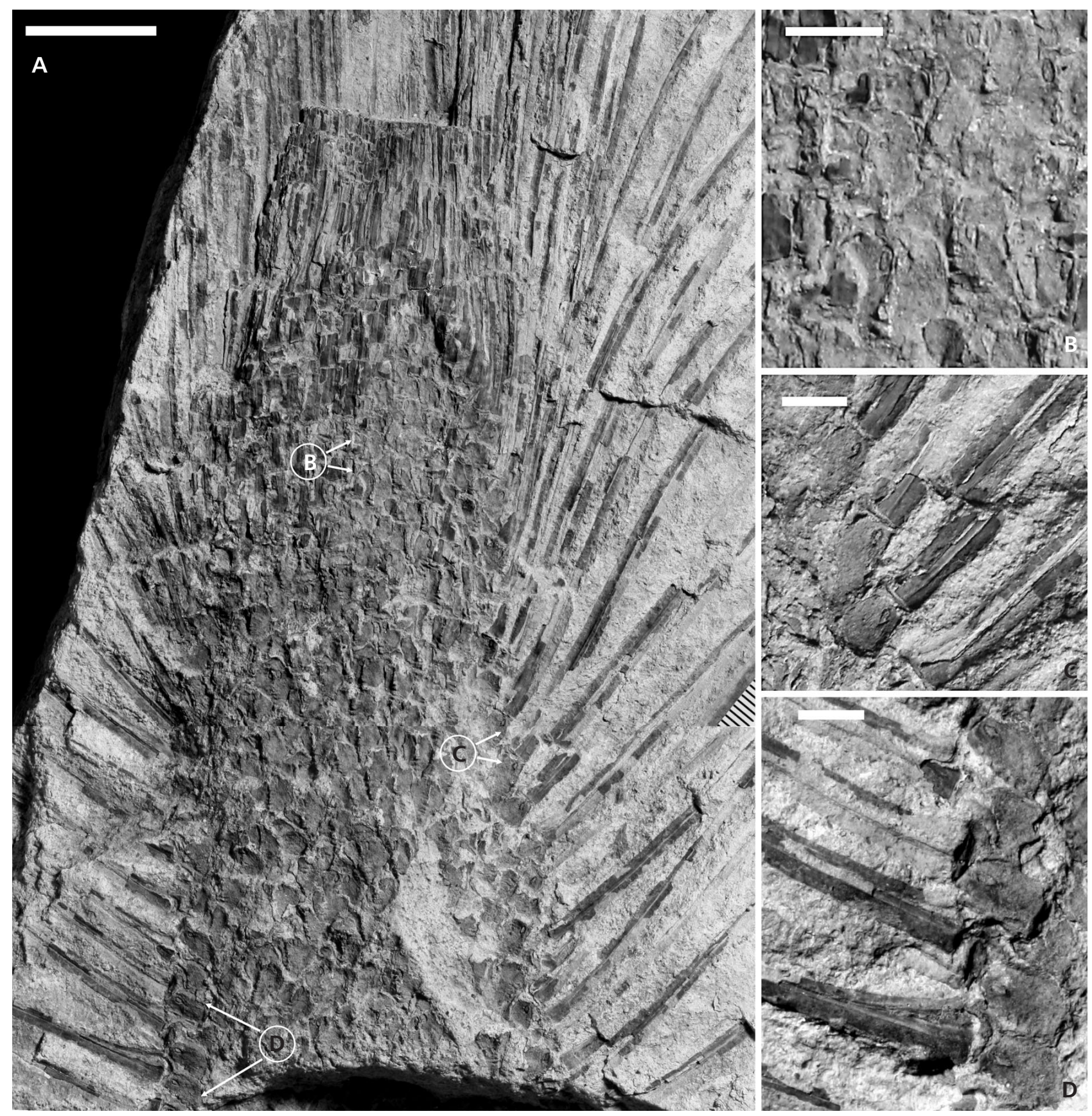

Figure 2. A - detail of the apex of the Specimen No. 6857. Scale bar $20 \mathrm{~mm}$. B - detail of leaf cushion near the apex. For precise position see the Fig. 2A. Scale bar $5 \mathrm{~mm}$. $\bullet \mathrm{C}$ - detail of lateral view of leaf cushions with leaves from the Fig. 2A. Note the infrafoliar parichnos imprints and character of connection of leaves to the cushions. For position see the indication in Fig. 2A. Scale bar $5 \mathrm{~mm}$. D - lateral view of leaf cushions with attached leaves. For location see Fig. 2A. Scale bar $5 \mathrm{~mm}$.

laterally positioned leaf cushions are inserted at an angle of about $70-75^{\circ}$ to the stem axis, however, near the apex this angle starts to rapidly decrease so the leaves at the apex are parallel to the stem axis. This change in leave orientation is indicated also by direction of leaf cushions located along the margins of compressed stem (Fig. 2A) and leaf bases, which follow the same pattern of orientation. The leaf bases are clearly separated from the leaf cushions by a straight narrow line (Fig. 2B, C). Leaves on the opposite side of the stem were folded during burial. Therefore they are directed downward and are preserved and partly exposed in a plane few millimetres beneath the stem.

The remaining four specimens represent mature ontogenetic stages of the same species. Specimen E 5734 is 


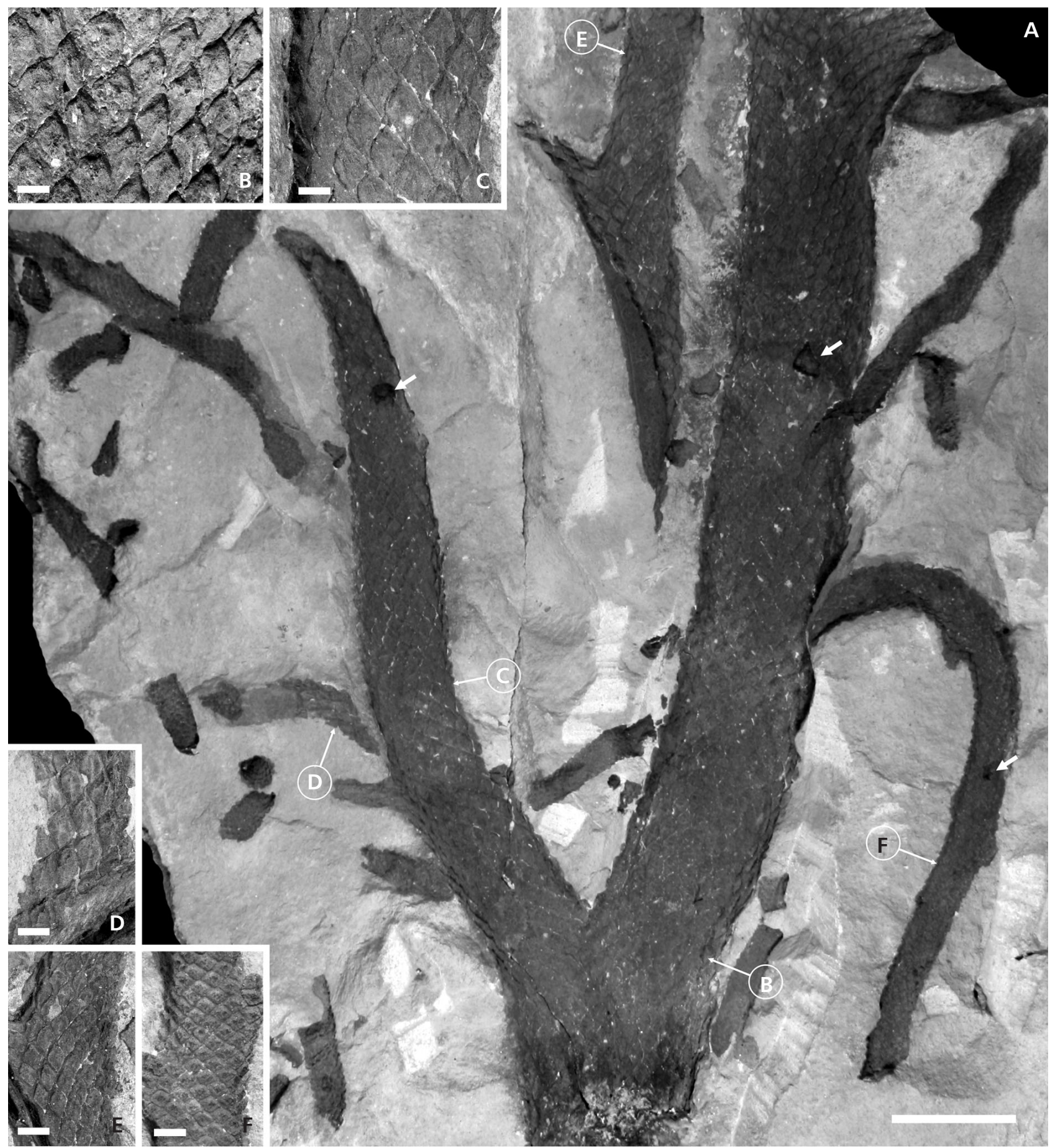

Figure 3. A - the specimen E 5734 (National Museum in Prague). Short thicker arrows without an encircled letter point to hollow left by branch protruding into the rock. Scale bar $50 \mathrm{~mm}$. B-F - details of leaf cushions from various parts of the specimen. For location see the letters with arrows pointing to the position of detailed pictures on a Fig. 3A. All scale bars are $5 \mathrm{~mm}$.

a rectangular slab about $500 \mathrm{~mm}$ long that preserves the impression of part of a branch system (Fig. 3A) of about middle crown. It exhibits two types of branching, dichotomous and pseudomonopodial. In the lower part of the slab, a branch about $72 \mathrm{~mm}$ wide is divided by slightly anisotomous dichotomy into branches of 56 and $40 \mathrm{~mm}$ in diameter. These two forks diverge at an angle of $55^{\circ}$. The thicker of them probably bifurcates again about $420 \mathrm{~mm}$ above the previous dichotomy as indicated by an apparent increase in diameter of the branch at the slab margin and by 


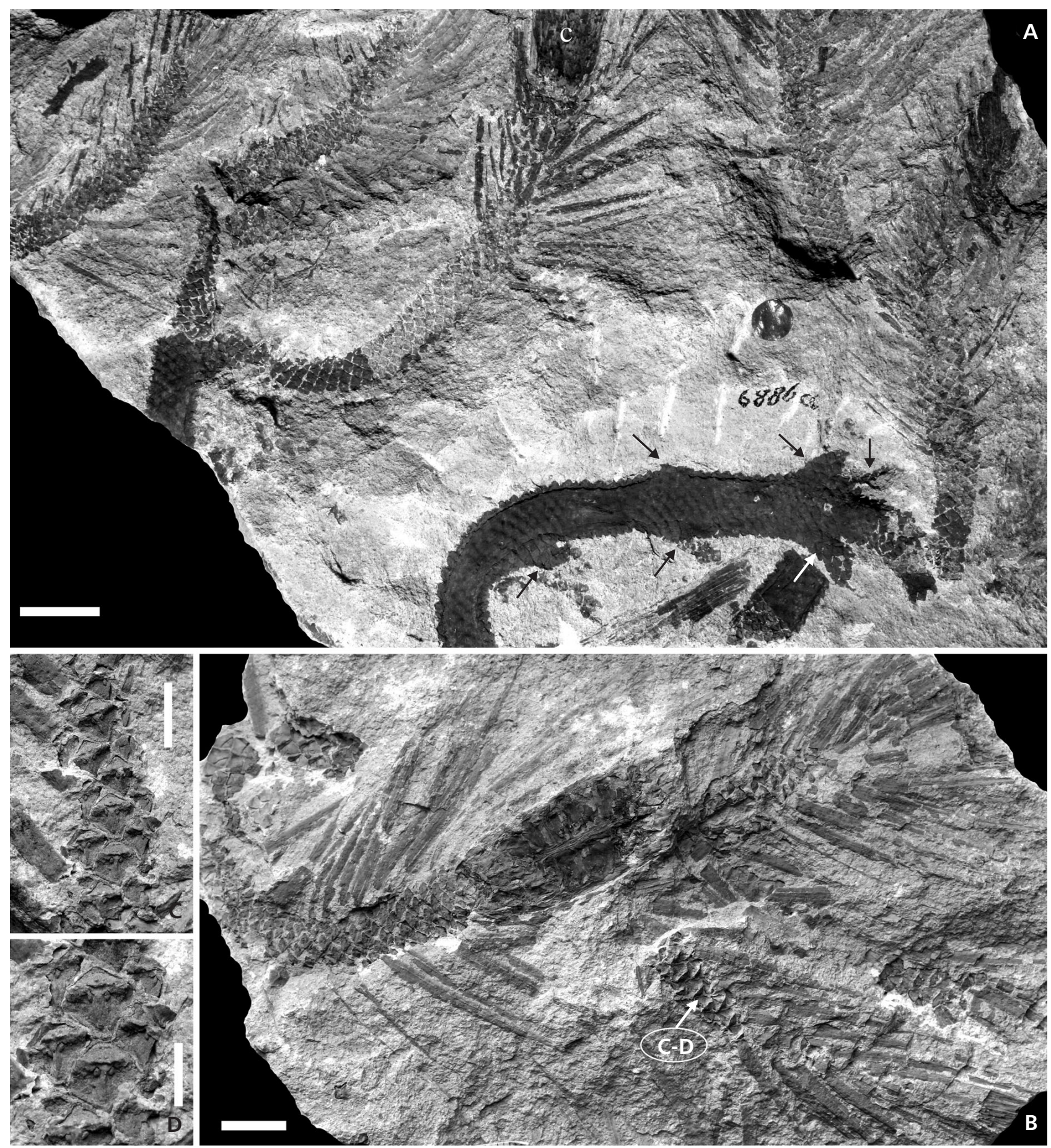

Figure 4. A - the specimen No. 6886 (Geologische Bundesanstalt Museum, Vienna) showing leafy shoots one of them terminated with cone (c). Note the leaves are only preserved near the apex. Arrows indicate position of branching. Scale bar $20 \mathrm{~mm}$. B - leafy shoot terminated with cone. The specimen F 233 (West Bohemian Museum in Pilsen). Scale bar $10 \mathrm{~mm}$. $\bullet$ C detail of leafy shoot from the specimen in the Fig. 4B. Scale bar $5 \mathrm{~mm}$. $\bullet$ D - detail of leaf cushions from shoot in Fig. 4C. Scale bar $3 \mathrm{~mm}$.

the change in direction of the leaf cushions. Both these, which were part of the dichotomizing "crown" branches, bear several smaller isotomous lateral branches (Fig. 3A). These lateral branches attain only about $25-40 \%$ of the thickness of the main branch, which they depart at angles as high as $60^{\circ}$ and $65^{\circ}$. However, with increasing distance from their point of forking they bend downward (Fig. 3A). Neighbouring branches are about $30-70 \mathrm{~mm}$ apart and they seem to be randomly arranged. Hollows in the both main dichotomies (Fig. 3A) indicate branches protruding into 


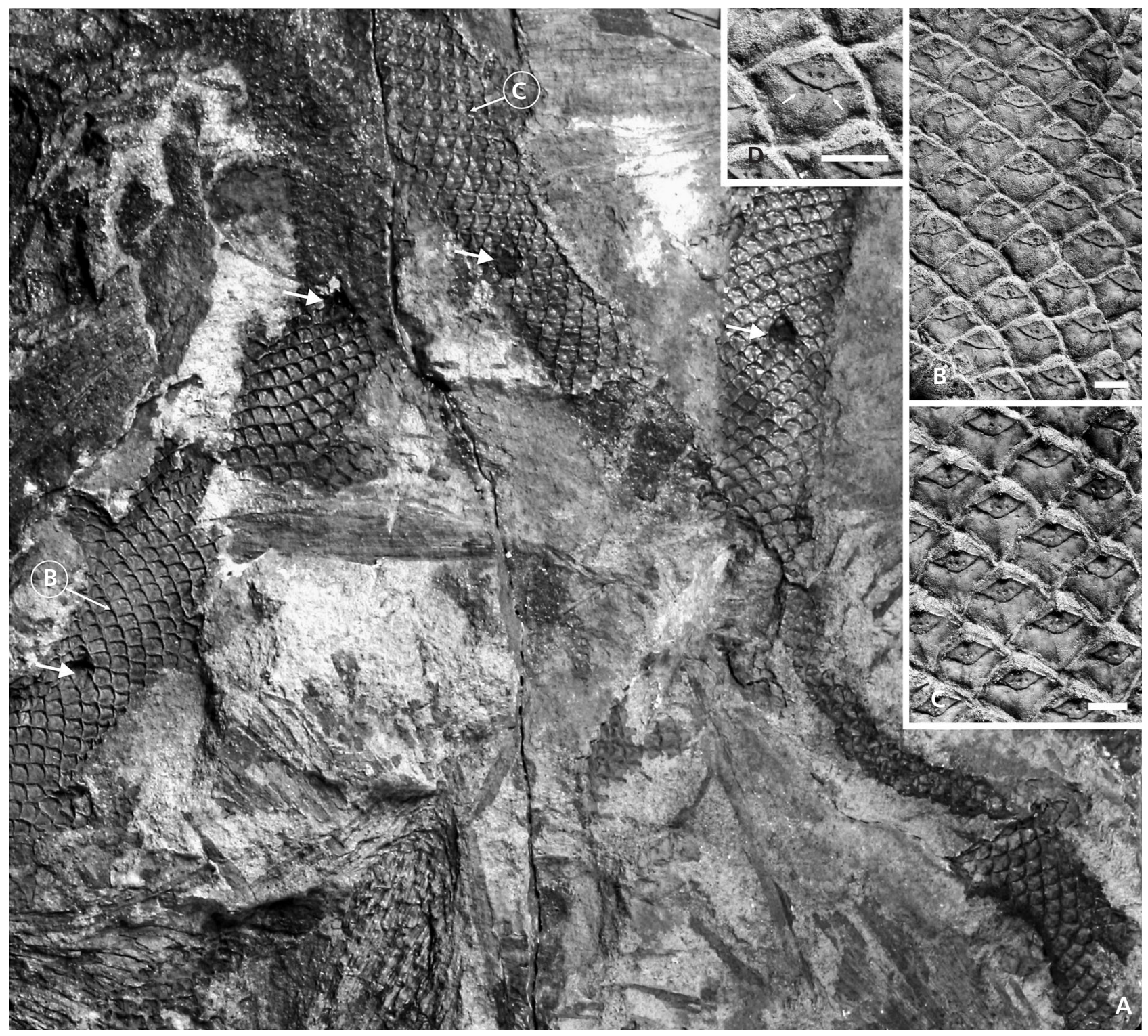

Figure 5. A - the specimen E 4745 (National Museum in Prague). Impression of terminal and near-terminal shoots and branches. Arrows without encircled letters point to hollows left by pseudomonopodial branch bases pointing to the rock. Scale bar $10 \mathrm{~mm}$. B, C - detail of leaf cushions from the specimen E 4745. Infrafoliar parichnos imprints are absent probably as a result of preservation. For location see Fig. 5A. Scale bar $5 \mathrm{~mm}$. $\mathrm{D}-\mathrm{detail}$ of leaf cushion from Fig. 3B showing infrafoliar parichnos (indicated by arrows). Scale bar $5 \mathrm{~mm}$.

the rock since this specimen is an impression, whereas on compression it would be slightly raised thus resembling tubercles of Halonia branches. Although these pseudomonopodially borne branches are only between 14 and $19 \mathrm{~mm}$ thick they display another order of branching. However, these second order pseudomonopodial branches are all broken and only bases, not longer than $1 \mathrm{~cm}$, are preserved (Fig. 3A, F). However, remains of these second order branches are not present with the rest of the remains, as might be expected if they were broken off during burial of the branch. These bases, about 10 to $12 \mathrm{~mm}$ thick, may be located at any point on the circumference of the branches; those along the margins are in a slightly alternating position perhaps indicating a helical arrangement. Neighbouring branches within a helix are about 50-70 $\mathrm{mm}$ apart. Although only branch bases are preserved, the angles at which these branches depart are comparable with angles between larger branches. All branches in this slab are leafless but they display leaf cushions. The size of the leaf cushions is approximately the same between branches but decreases as stem diameter shrinks acropetally (Fig. 3B-F). The apparent absence of leaves, even isolated in the rock, may indicate that this branch system represents the rather older part of the canopy, from which leaves had 
abscised already before volcanic ash fall. There is no sudden change in size and shape of leaf cushions below and above dichotomies. Instead it is more gradual over distance of several tens of centimetres. However, this contrast exists between thick branches and much thinner pseudomonopodial branches they bear. Leaf cushions of the pseudomonopodial branches are apparently smaller and shorter (Figs 3, 6).

Specimens No. 6886, F 233 and E 4745 preserve terminal leafy shoots, some showing isotomous and/or anisotomous branching. Specimen No. 6886 displays anisotomously branched shoots (Fig. 4A), which are 14 to $16 \mathrm{~mm}$ wide, one of them curved arch-like. This axis branches pseudomonopodially, the lateral shoots borne about $35 \mathrm{~mm}$ apart. Both branch and shoot bases are leafless. Another of the shoot fragments is about $6 \mathrm{~cm}$ long and $13 \mathrm{~mm}$ wide and bears arch-like bent lateral shoot that terminates with a cone at the tip. This terminal shoot is 10-12 mm wide and about $130 \mathrm{~mm}$ long (without cone) bearing leaves for about $40 \mathrm{~mm}$ below the cone. There are at least five more or less complete isolated remains of terminal shoots partly clothed in leaves, of similar diameter to the one in organic connection to the parent branch. Some of these shoots have preserved apices with leaves. The part of shoot with leaves can be up to $65 \mathrm{~mm}$ long. Grass-like leaves of the terminal shoots are more than $55 \mathrm{~mm}$ long (estimated length is about 75 to $80 \mathrm{~mm}$ ) and about $2.5 \mathrm{~mm}$ wide near the base from which they gradually taper to the apex. Leaf cushions of terminal shoots are wider than long; their length varies from 2.7 to $3.3 \mathrm{~mm}$ whereas width is between 3.5 and $4.1 \mathrm{~mm}$ (Fig. 4C).

Specimen F 233 preserves remains of about 6 terminal shoots (Fig. 4B). The largest one is a fragment, about $6 \mathrm{~cm}$ long, of an arch-like bent terminal shoot with a male cone at the tip and leaves near the apex. One of the other remains represents an apical part of terminal leafy shoot only $6 \mathrm{~mm}$ in diameter. Leaf cushions of these terminal branches are between 2.7 and $3.5 \mathrm{~mm}$ long and from 3.1 to $3.7 \mathrm{~mm}$ wide (Fig. 4C, D). The male cone of L. mannebachense is Lepidostrobus obovatus, which produced Lycospora loganii microspores (Bek \& Opluštil 2004). These cones are often found in organic connection with the leafy shoot of the parent plant, L. mannebachense whereas female cones are unknown.

Specimen E 4745 bears fragments of several shoots of two different diameters (Fig. 5). The thicker shoots are leafless, about 16-18 $\mathrm{mm}$ in diameter. They bear bases of thinner pseudomonopodial branches. These branch bases correspond in diameter to thinner leafy terminal shoots scattered on the slab surface. Leaf cushions are of diamond shape between 3.2 and $3.5 \mathrm{~mm}$ long and from 3.8 to $3.9 \mathrm{~mm}$ wide (Fig. 5B, C). Most of them have poorly preserved infrafoliar parichnos markings, although these can be identified on some cushions (Fig. 5D).
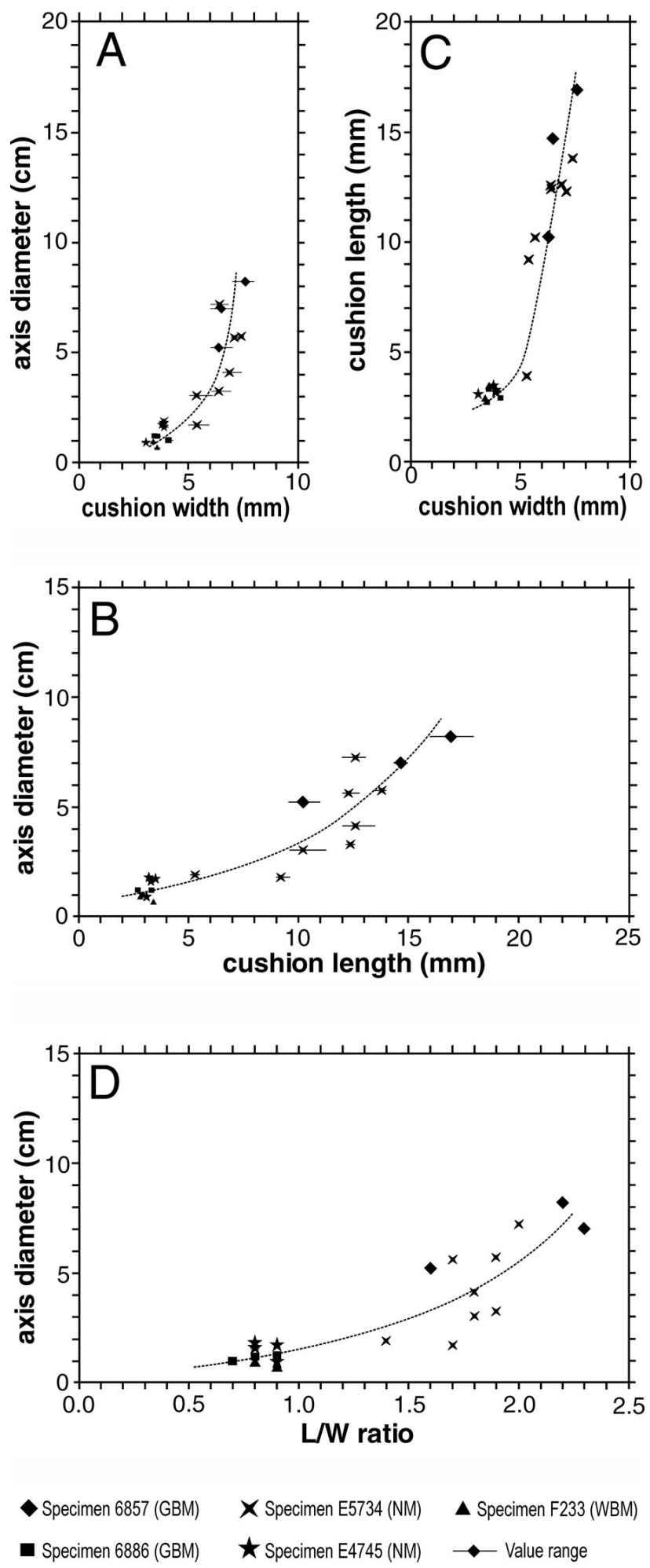

Figure 6. Relationship between axis diameter and various leaf cushion parameters as measured at the specimens described herein. For thorough explanation see the text. - A - relationship between axis diameter and leaf cushion width. $-\mathrm{B}$ - relationship between axis diameter and leaf cushions length. - $\mathrm{C}$ - relationship between leaf cushions width and length. $-\mathrm{D}$ - relationship between axis diameter and leaf cushion L/W (length/width) ratio. 
All of the specimens in the studied collections and identified as L. mannebachense do not display ulodendroid branch scars.

\section{Discussion}

Specimen No. 6857 most likely represents the apical part of the stem of Lepidodendron mannebachense before it reached the first branching otherwise the specimen would be slightly curved and/or dichotomously divided or shows densely spaced pseudomonopodially-born branches, as seen in other specimens described herein. This interpretation is also indicated by the straight leafy axis, blunt apical termination, and insertion of leaves at the apex. In addition, leaf length in this specimen is much larger than that in specimens with smaller leaf cushions. Leaves of terminal leafy shoots are not longer than 100 mm (e.g. Němejc 1947; Bek \& Opluštil 1998, 2004). Inter-cushion areas have never been observed on any specimen in the studied collections. This may indicates that L. mannebachense had probably a limited potential to accommodate stem thickening due to secondary growth by expansion of inter-cushion areas. As a result, these outer cortical tissues were probably soon sloughed off and only a narrow zone of primary cortex remained on the stem below the apex as in the case of this specimen. On the contrary, bark fragments of similar species L. aculeatum often display inter-cushion areas well developed, although Thomas \& Watson (1976) observed closely spaced (!) leaf-cushion outlines $18 \mathrm{~m}$ above the base of $34.5 \mathrm{~m}$ long trunk of this species. Leary and Thomas (1989) described about $6 \mathrm{~m}$ long stem of L. aculeatum, which still bear leaves along whole length. This suggests existence of other mechanisms of leaf-cushion retention as in the case of L. hickii (a possible anatomically preserved equivalent of $L$. aculeatum) where there was extensive lateral expansion of cells in basal cushion parenchyma and periderm resulting in "stretching" not only of inter-areas but partly also of leaf cushions (DiMichele 1983).

The size of leaf cushions of L. mannebachense changed from the base to the top of tree. Observations of the specimens and their morphometric analysis proved that leaf cushions reduce in size, both length and width, as the thickness of the axis decreases. This is in agreement with Eggert (1961) who suggested that cushion dimensions reflect the size of meristem, which is reduced with each branching, especially with apical dichotomy. However, whereas the length of leaf cushions significantly decreases with reduced axis diameter, changes in width are much less ap- parent (Fig. 6A, B). The length of the leaf cushions of the described specimens varies from of 2.7 to $18 \mathrm{~mm}$ (Fig. 6B). The largest leaf cushions known to the author has one of Thomas (1970) specimens (plate 32, fig. 2) the length of which is about $22 \mathrm{~mm}$. Since primary cortical tissues form the leaf cushions their length is permanently fixed once the primary tissues matured (Eggert 1961, Wnuk 1986). The length of leaf cushions therefore reflects the size of the cushions at the time of their formation (Wnuk 1986). Reduction of length also was observed just below the dichotomy preserved on specimen E 5734. This reduction is explained as a response to decrease in growth rate of the apical meristem prior to dichotomy (Wnuk 1986). The width of the cushions decreases from maximum values of about $9 \mathrm{~mm}$ to minimum width on terminal shoots of about $3.1 \mathrm{~mm}$ (Fig. 6C). The consequence of more rapid decrease of cushion length than of width is that leaf cushions of terminal shoots, i.e. usually those less than $15 \mathrm{~mm}$ in diameter, are wider than long (Fig. 6D).

Branching observed on the study specimens clearly show two types of patterns. The basic pattern concerns main branches produced by isotomous to slightly anisotomous dichotomies that built the base of determinate crown. These "main" branches bear smaller pseudomonopodial and strongly anisotomous lateral branches densely located at any point on the circumference only several centimeters apart. These branches, in turn, bear even smaller second order pseudomonopodial branches some of them terminated by cones. Unfortunately, the material is too fragmentary to estimate the rate between leafy and cone-bearing branches.

Combination of these two branching patterns suggests that the stem started to split by apical dichotomy and this branching pattern continued throughout the whole canopy until a determinate growth limit was reached. The average number of dichotomies is difficult to estimate because material is fragmentary; nevertheless, specimen E 5734 (Fig. 3) shows that dichotomies could be quite frequent about half a meter apart or even less. This branching pattern is in agreement with absence of ulodendroid scars typical for arborescent lycopsids where canopy is formed by pseudomonopodial branching (e.g. DiMichele \& Phillips 1994). It is therefore suggested that L. mannebachense had an umbrella-like character as proposed already by Hirmer (1927, fig. 200). Apart from Hirmer's reconstruction, however, branches resulting from these dichotomies bear anisotomous lateral branches, which, subsequently produce another order of thinner lateral branches representing terminal shoots, some of them bearing cones at least. These second-order lateral branches are very often

Figure 7. The whole plant reconstruction of Lepidodendron mannebachense. $\bullet$ A - juvenile unbranched stem with leafy upper part of stem. $\bullet$ B - matured stage showing crown built of combination of dichotomous and pseudomonopodial branching. $\bullet \mathrm{C}-$ detail of a branch of matured tree. Leaves are omitted. Drawn by J. Svoboda. 

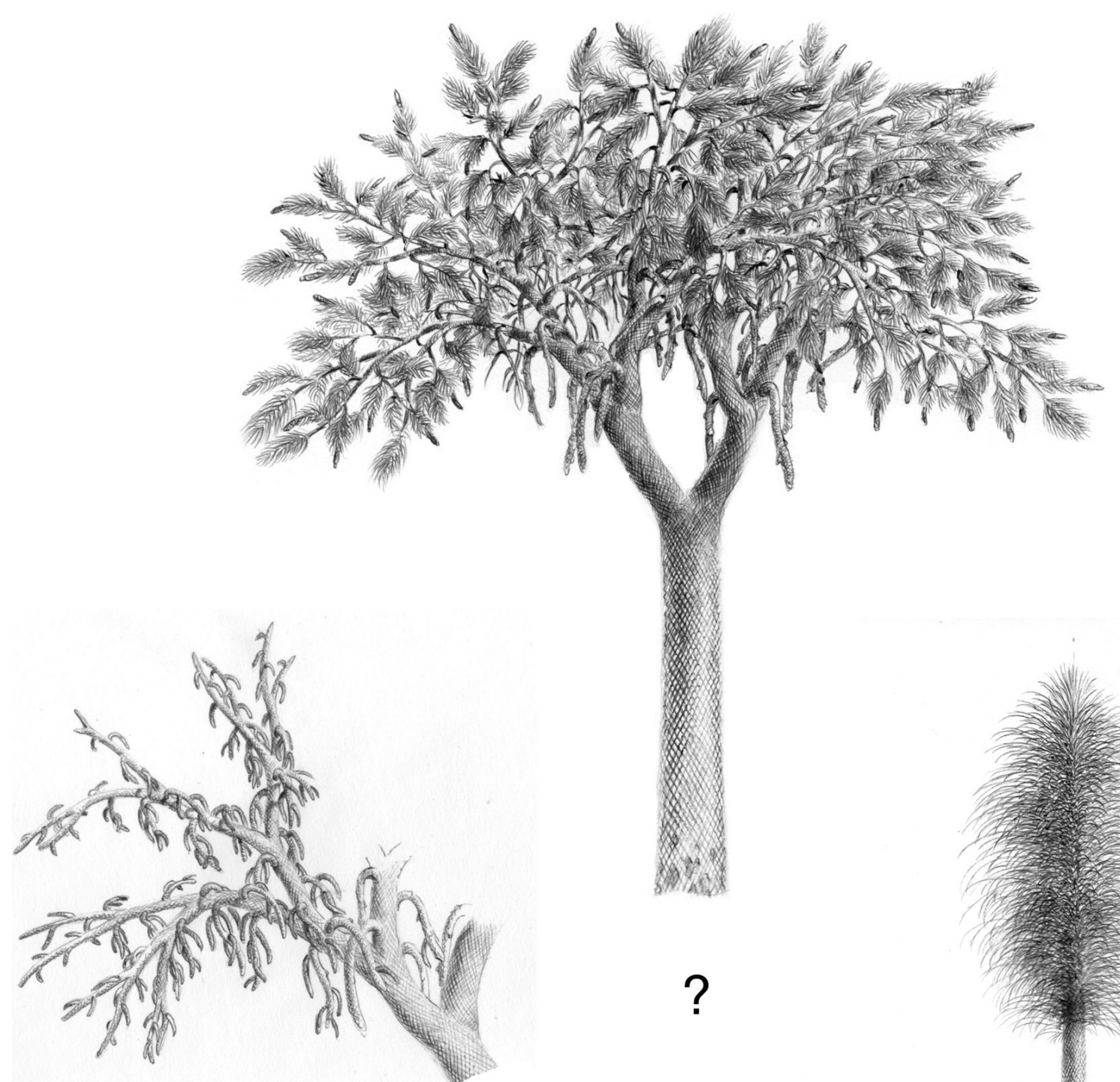

C

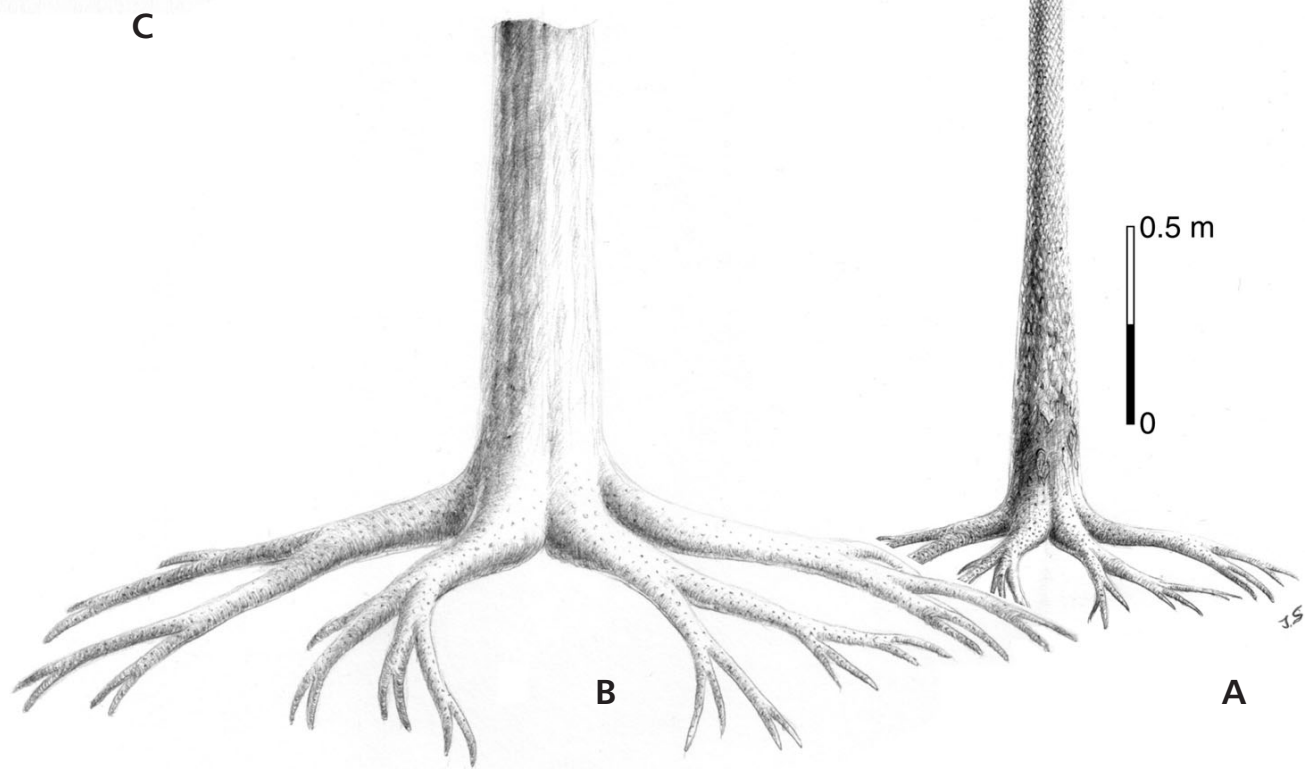


preserved only as branch bases resembling tubercles of Halonia which also represent bases of small lateral branches on major Lepidophloios branches (e.g. Weiss 1903). Common presence of leaf bases suggests that they were shed during the life of the tree when they lost their leaves and were themselves shed, probably as the cones, they bore, matured. We can speculate that most of the photosynthate sugars supplied local tissues growth and development since lepidodendrid lycopsids had a very limited phloem system to transport photosynthates around (e.g. DiMichele 1983, Phillips \& DiMichele 1992). Once local tissues matured, the leaves were no longer needed. These small cone-bearing lateral branch systems of Lepidodendron mannebachense are similar in function to lateral branches of continuously reproducing arborescent lycopsids like Diaphorodendron and Paralycopodites which Bateman \& DiMichele (1991) and Bateman (1994) considered as to be the homologues of cone peduncles in those lycopsids with short pedunculate attachements bearing a single cones (e.g. Lepidophloios and Sigillaria). The lateral cone-bearing branch system of L. mannebachense is in architecture closer to those of Diaphorodendron and Paralycopodites whereas Lepidophloios and Sigillaria represent the most reduced state.

Shortening of leaves with each subsequent branching is also evident from the specimens described here. This is consistent with reduction of leaf cushions in a similar way throughout the crown of the plant and in different taxa due to reduction of meristem size after each branching (Eggert 1961; DiMichele 1979a, b, 1981). Absence of leaves at most branches except for the terminal shoots indicates that leaves had a short functional life span and were abscised early. This is in agreement with the author's observations of many specimens of this species, which are mostly preserved as leafless bark compressions/impressions.

Unfortunately, the specimens described herein are insufficient for estimation of the height of the mature tree. Although Niklas (1984) derived formulae for estimation of the height of plants of various growth forms, the basic parameter, the diameter at breast height is not known. Moreover, except specimen No. 6857 preserving apical part of the juvenile stem, there is no other specimen known to the present author, which preserves clearly both sides of the stem to calculate the height of the plant. Surprisingly, the widest but still incomplete stem fragment ever observed in the collection is only about $100 \mathrm{~mm}$ wide, which is much less than the similar species, Lepidodendron aculeatum, where stem fragments are commonly more than $200 \mathrm{~mm}$ wide (max. more than $500 \mathrm{~mm}$, Libertín et al. 2009b). This disproportion suggests that either L. mannebachense was smaller tree than L. aculeatum (probably about 15-20 m tall if the diameter was about $15-20 \mathrm{~cm}$ ) thus producing smaller bark fragments or that its stem decorticated in smaller pieces than that of L. aculeatum. We can speculate that L. mannebachense could decorticate more easily comparing to $L$. aculeatum as indicated by absence of evidence of inter-cushion area development in former species.

\section{Restoration of ontogenetic development of L. mannebachense}

The development of aerial part of L. mannebachense most probably followed the pattern of other lepidodendrid lycopsids (Andrews \& Murdy 1958, Eggert 1961, Phillips \& DiMichele 1992). It started as unbranched tall columnar stem before branching occurred.

This unbranched stage of development was probably a period of rapid growth (e.g. Wnuk 1986, Phillips \& DiMichele 1992). It is suggested here that the canopy was established and then elaborated by means of apical dichotomies. These dichotomies continued till the determinate limit was reached. For L. mannebachense the width of the apical part of terminal shoots is about 6 to $10 \mathrm{~mm}$. It is assumed that this species had an umbrella-like canopy as suggested by Hirmer (1927). However, most of the terminal shoots were thin cone-bearing lateral branches produced by anisotomous pseudomonopodial branching of two orders (Fig. 7). Although these lateral branch systems occur throughout the tree crown, this final (apoxogenic) phase of tree development represents relatively short period of time when reproduction occurred. L. mannebachense thus can be considered as a monocarpic plant with reproduction at the end of its life cycle comparing to lycopsids with deciduous lateral branch systems produced up the stem with much more extended period of reproduction, lasting much of the life of the aerial part of the plant.

Leaves of L. mannebachense were longest on the main unbranched stem, and their length decreased as branch diameter and leaf-cushion size reduced with each dichotomy. This mode of development is characteristic not only of this species but also for other lepidodendrid species (Lindley \& Hutton 1833, 1835; Hirmer 1927; Andrews 1961; Eggert 1961; Wnuk 1985). Leaf functional life span was probably quite short after which leaves were shed from stems or branches leaving a characteristic scar. Consequently, only zone with leaves was maintained on the plant in any developmental stage. However, it is currently impossible to specify the width of this zone from specimens available. Leary \& Thomas (1989) observed attached leaves along about $6 \mathrm{~m}$ long remain of the main stem of similar but probably a larger species $L$. aculeatum. At the final stage of its life cycle, leaves were retained only on terminal branches or even their apical parts. Primary cortical tissues have no potential to compensate stem/branch thickening produced by secondary growth. Leaf cushions therefore, were probably sloughed off quite soon and persisted on a stem only in a zone near the current apex. A similar growth pattern, 
with determinate umbrella-like canopy, as proposed here for L. mannebachense is characteristic of all monocarpic forms of lepidodendrid lycopsids (see Phillips \& DiMichele 1992 or DiMichele \& Phillips 1994 for an overview). L. mannebachense is a representative of the genus Lepidodendron in the sense of DiMichele (1979b, 1981, 1983) who segregated Lepidodendron "sensu stricto" based on stem anatomy linked to certain leaf cushion attributes (especially infrafoliar parichnos), from the original concept of Sternberg relying only on leaf cushion shape.

\section{Acknowledgement}

This contribution to Carboniferous palaeobotany was supported by the project MSM 0021620855 of the Faculty of Science, Charles University in Prague, which allowed the author to visit and study the specimen in the collection of the Geologische Bundesanstalt Museum in Vienna, Austria. The author is also very grateful to B. Meller, a curator of the palaeobotanical collection in this institution for providing access to specimens No. 6857 and No. 6886. M. Libertín (National Museum in Prague) and J. Pšenička (West Bohemian Museum in Pilsen) are thanked for making accessible the specimens E 5734, E 4745 and F 233, respectively, for detailed study. The paper benefited significantly from thorough and constructive review of B.A. Thomas (Aberystwyth University, UK) and W.A. DiMichele (Smithsonian Institution, Washington, USA) who also provided a language correction of the manuscript. J. Svoboda is thanked for drawing of the Figure 7.

\section{References}

ANDREWS, H.N. \& MURDY, W.H. 1958. Lepidophloios and ontogeny in arborescent lycopods. American Journal of Botany 45, 552-560. DOI $10.2307 / 2439579$

BATEMAN, R.M. 1994. Evolutionary-developmental change in growth architecture of fossil rhizomorphic lycopsids: scenarios constructed on cladistic foundations. Biological Reviews 69, 527-597. DO1 10.1111/j.1469-185X.1994.tb01249.x

BATEMAN, R.M. \& DiMichelE, W.A. 1991. Hizemodendron, gen. nov., a pseudoherbaceous segregate of Lepidodendron (Pennsylvanian): Phylogenetic context for evolutionary changes in lycopsid growth architecture. Systematic Botany 16, 195-205. DOI $10.2307 / 2418983$

BEK, J. \& OPLUŠTIL, S. 2004. Palaeoecological constraints of some Lepidostrobus cones and their parent plants from the Late Palaeozoic continental basins of the Czech Republic. Review of Palaeobotany and Palynology 131, 49-89.

DOI 10.1016/j.revpalbo.2004.02.008

DELEVORYAS, T. 1964. Ontogenetic studies of fossil plants. Phytomorphology 14, 299-314.

DiMiCHELE, W.A. 1979a. Arborescent lycopods of Pennsylvanian age coals: Lepidophloios. Palaeontographica, Abteilung B 171, 57-77.
DiMichele, W.A. 1979b. Arborescent lycopods of Pennsylvanian age coals: Lepidodendron dicentricum C. Felix. Palaeontographica, Abteilung B 171, 122-136.

DiMichele, W.A. 1980. Paralycopodites Morey \& Morey, from the Carboniferous of Euramerica - a reassesment of generic affinities and evolution of Lepidodendron brevifolium Williamson. American Journal of Botany 67, 1466-1476. DOI $10.2307 / 2442875$

DiMiCHELE, W.A. 1981. Arborescent lycopods of Pennsylvanian age coals: Lepidodendron with description of a new species. Palaeontographica, Abteilung B 175, 85-125.

DiMichelE, W.A. 1983. Lepidodendron hickii and generic delimitation in Carboniferous lepidodendrid lycopods. Systematic Botany 8(3), 317-333. DOI 10.2307/2418485

DiMichele, W.A. \& PHILLIPS, T.L. 1985. Arborescent lycopod reproduction and paleoecology in a coal-swamp environment of late Middle Pennsylvanian age (Herrin Coal, Illinois). Review of Palaeobotany and Palynology 44, 1-26.

DO] 10.1016/0034-6667(85)90026-0

DiMichele, W.A. \& PHILliPS, T.L. 1994. Paleobotanical and paleoecological constraints on models of peat formation in the Late Carboniferous of Euramerica. Palaeogeography, Palaeoclimatology, Palaeoecology 106(1-4), 39-90. DOI 10.1016/0031-0182(94)90004-3

EGGERT, D.A. 1961. The ontogeny of Carboniferous arborescent lycopsida. Palaeontographica, Abteilung B 108, 43-92.

ETtingshausen, C. 1854. Die Steinkohleflora von Radnitz in Böhmen. Abhandlungen der kaiserlich-königlichen geologischen Reichsanstalt II(3), 1-74.

HIRMER, M. 1927. Handbuch der Paläobotanik. Band I: Thallophyta, Bryophyta, Pteridophyta. 724 pp. R. Oldenburg Verlag, Munich.

LEARY, L.L. \& THOMAS, B.A. 1989. Lepidodendron aculeatum with attached foliage: evidence of stem morphology and fossilization processes. American Journal of Botany 76(2), 283-288. DOI 10.2307/2444670

LIBERTín, M., OPLUŠTIL, S., PŠENIČKA, J., BEK, J., SÝKOROVÁ, I. \& DAŠKOVÁ, J. 2009a. Middle Pennsylvanian pioneer plant assemblage buried in situ by volcanic ash-fall, central Bohemia, Czech Republic. Review of Palaeobotany and Palynology 155(3-4), 204-233.

DOI 10.1016/j.revpalbo.2007.12.012

LIBERTíN, M., DAŠKOVÁ, J., OPLUŠTIL, S., BEK, J. \& EDRESS, N. 2009b. A palaeoecological model for a vegetated early Westphalian intramontane valley (Intra-Sudetic Basin, Czech Republic). Review of Palaeobotany and Palynology 155(3-4), 175-203. DOI 10.1016/j.revpalbo.2008.07.002

LINDLEY, J. \& HUTTON, W. 1835. The fossil flora of Great Britain; or figures and descriptions of the vegetable remains found in a fossil state in this country. Volume 2. 208 pp. J. Ridgeway, London.

MacGregor, M. \& WALton, J. 1948. The story of the fossil grove of Glasgow Public Parks and Botanical Gardens, Glasgow. 32 pp. City of Glasgow Public Parks and Botanic Gardens Department, Glasgow.

NĚMEJC, F. 1946. Further critical remarks on Sternberg's Lepidodendron dichotomum and its relations to the cones of 
Sporangiostrobus Bode. Rozpravy II. třídy České akademie věd 47(7), 1-11.

NĚMEJC, F. 1947. The Lepidodendraceae of the coaldistricts of Central Bohemia. Sborník Národního musea 7 B(2), $45-87$.

NĚMEJC, F. 1963. Paleobotanika II. 523 pp. Nakladatelství Československé akademie věd, Praha.

NIKLAS, K.J. 1994. Predicting the height of fossil plant remains: an allometric approach to an old problem. American Journal of Botany 81(10), 1235-1242. DOI 10.2307/2445398

OpluŠTIL, S., PŠENIČKA, J., LIBERTín, M. \& ŠIMŮNEK, Z. 2007. Vegetation patterns of Westphalian and Lower Stephanian mire assemblages preserved in tuff beds of the continental basins of Czech Republic. Review of Palaeobotany and Palynology 143, 107-154.

DO] 10.1016/j.revpalbo.2006.06.004

OPLUŠTIL, S., PŠENIČKA, J., LIBERTÍN, M., BASHFORTH, A.R., ŠIMŮNEK, Z., DRÁBKOVÁ, J. \& DAŠKOVÁ, J. 2009a. A Middle Pennsylvanian (Bolsovian) peat-forming forest preserved in situ in volcanic ash: The Whetstone Horizon in the Radnice Basin, Czech Republic. Review of Palaeobotany and Palynology 155(3-4), 234-274.

DO] 10.1016/j.revpalbo.2009.03.002

OPLUŠTIL, S., PŠENIČKA, J., LIBERTÍN, M., BEK, J., DAŠKOVÁ, J., ŠIMƯNEK, Z. \& DRÁBKOVÁ, J. 2009b. Composition and structure of an in situ middle Westphalian peat-forming plant assemblage buried in volcanic ash, Radnice Basin (Czech Republic). Palaios 24, 726-746. DOI 10.2110/palo.2008.p08-128r.

PhILliPS, T.L., PEPPERS, R.A. \& DiMichele, W.A. 1985. Stratigraphic and interregional changes in Pennsylvanian coal-swamp vegetation: environmental inferences. International Journal of Coal Geology 5, 43-109.

DOI 10.1016/0166-5162(85)90010-2

PhILliPS, T.L. \& DiMichele, W.A. 1992. Comparative ecology and life-history biology of arborescent lycopsids in Late Carboniferous swamps of Euramerica. Annals of the Missouri Botanical Garden 79(3), 560-588. DOI 10.2307/2399753

SCOTT, D.H. 1920. Studies in Fossil Botany. I. (3 ${ }^{\text {rd }}$ edition). A. and C. Black, London.

STERNBERG, C. VON 1820-1838. Versuch einer geognostichbotanischen Darstellung der Flora der Vorwelt. Pt. 1: (1820), 24 pp. Pt. 2: (1821), 33 pp. Pt. 3: (1823), 39 pp. Pt. 4: (1825), 42 pp. Pt. 5 and 6: (1833), 80 pp. Pt. 7 and 8: (1838), 291 pp. Leipzig \& Prague.

THOMAS, B.A. 1966. The cuticle of Lepidodendroid stem. New Phytologist 65, 296-303.

DO1 10.1111/j.1469-8137.1966.tb06365.x

THOMAS, B.A. 1970. Epidermal studies in the interpretation of Lepidodendron species. Palaeontology 13(1), 145-173.

Thomas, B.A. \& WATSON, J. 1976. A rediscovered 114-foot Lepidodendron from Bolton, Lancashire. Geological Journal 11(1), 15-20.

WALTON, J. 1935. Scottish Lower Carboniferous plants: the fossil hollow trees of Arran and their branches (Lepidophloios wunchianus Carruthers). Transactions of the Royal Society Edinburgh 58, 313-338.

WEISS, F.E. 1903. A biseriate halonial branch of Lepidophloios fuliginosus. Transactions of the Linnean Society, Botany, series 2, 6(1901-1905), 217-235.

WNUK, C. 1985. The ontogeny and paleoecology of Lepidodendron rimosum and Lepidodendron bretonense trees from the Middle Pennsylvanian of the Bernice Basin (Sullivan County, Pennsylvania, U.S.A.). Palaeontographica, Abteilung B 195, 153-181. DOI 10.2307/2444518

WNUK, W. 1989. Ontogeny and paleoecology of the Middle Pennsylvanian arborescent lycopod Bothrodendron punctatum, Bothrodendraceae (western Middle Anthracite field, Shamokin quadrangle, Pennsylvania). American Journal of Botany 76(7), 966-980. 